\title{
ETHICAL LEADERSHIP: MEANING AND MEASUREMENT. LATVIAN RETAIL TRADERS' PERSPECTIVE
}

\author{
Velga Vēvere ${ }^{1}$, Iveta Lininạa ${ }^{2}$ \\ ${ }^{1}$ The University College of Economics and Culture, Latvia, velga.vevere@gmail.com \\ ${ }^{2}$ Turiba University, Latvia, iveta.linina@turiba.lv
}

\begin{abstract}
In the contemporary situation of ever-growing market internationalisation, local and global competition different company leadership aspects, especially ethical leadership, gain a special importance. It is possible to say that in theoretical literature, there is more or less consensual agreement upon the meaning of ethical leadership still regarding the evaluation models there are many models. Therefore, the main challenge is to determine the case sensitive model(s) for the industry or the type of business organisation. The goal of the article is to delineate theoretically and to test empirically amongst Latvian retail traders one of the models of evaluation (the one of the Executive Servant Leadership Scale, ESLS). The research questions are (1) What is the ranking of the ESLS first-order factors? and (2) What are the possible problem areas in the ethical leadership as seen by the Latvian retail traders? The authors of the present paper aspire to identify the problem areas out the future lines of investigation. The current research uses the following research methods: the monographic (the literature study related to the concept of ethical leadership and its evaluations models); expert interviews to narrow down the items to be tested; and the survey with the following factor analysis.
\end{abstract}

Keywords: ethical leadership; levels of ethical leadership; authentic leadership; transformational leadership; frameworks for analysis of ethical leadership

Type of the paper: Theoretical paper, Empirical study

JEL Classification: M14, L81

\section{Introduction}

In the contemporary situation of ever-growing market internationalisation, local and global competition different company leadership aspects gain a special importance. One of these aspects is ethical leadership. Implicit in the ongoing conversation regarding ethical leadership is the notion that leaders hold tremendous power and that those leaders who perceive organisations and people beyond 'competency inputs' and 'performance outputs' are increasingly important in a profoundly interdependent society (Reed et al. 2011). It is possible to say that in theoretical literature, there is more or less consensual agreement upon the meaning of ethical leadership still regarding the evaluation models there are many approaches. Therefore, the main challenge is to determine the case sensitive model(s) for the industry or the type of business organisation. The goal of the article is to delineate theoretically and to test empirically amongst Latvian retail traders one of the models of evaluation (the one of the Executive Servant Leadership Scale, ESLS). The research questions are: (1) What is the ranking of the ESLS first-order factors? and (2) What are the possible problem areas in the ethical leadership as seen by the Latvian retail traders? The authors of the present paper aspire to identify the problem areas out the future lines of investigation. The current research uses the following research methods: the monographic (the literature study related to the concept of ethical leadership and its measuring possibilities); expert interviews to narrow down the items to be tested; and the survey with the following factor analysis. During the past decade, the concept of ethical leadership gains more attention in management literature, both as a theoretical and a practical issue related to the sustainable development of the organisation. In the first part of the article, we perform a critical review of the literature regarding the conceptions of ethical leadership, as well as evaluation models. The second part is devoted to the empirical testing of one particular model - the ESLS - amongst the Latvian retail traders. 


\section{Literature Review}

In order to distinguish between various approaches to the concept and practice of ethical leadership, we propose to apply the three-level leadership model: ethics of the leader, the means of ethical leadership and the heart of leadership (Palmer 2009). Let us dwell briefly on each of the levels. First, there are theories concerning ethical behaviour of business leaders based on high personal moral standards and role modelling. It has been stressed that leaders who behave morally are probably less prone to moral transgressions in their business practices (Bowie 2005; Zaccaro et al. 2008). At the same time, we have to admit that this kind of approach can lead to holding leaders personally accountable to higher standards of morality that they are not being able to live up (Palmer 2009). Catherine Marsh (Marsh 2013) describes qualities such as mindfulness, engagement, authenticity and sustainment. The value perspective of mindfulness is composed of the valued approaches of ethical leadership: observation, time for reflection, systems thinking, rational process and dialogue and questioning. The value perspective of engagement embraces diversity, cultivates relationships, terminates relationships and encourages risk taking. Authenticity represents personal integrity and self-knowledge; sustainability is composed of the valued approaches of ethical leadership. The second group (level) of theories concerns the means of ethical leadership. This means to look for from the viewpoint of specific actions that are taken in performing leadership functions. Another way would be to view the means of leadership in terms of styles or models of leadership. The latter approach allows better understanding of the diverse actions within the particular leadership model. But the problem consists in the fact that none of the leadership styles is inherently moral or immoral, although some of them tend to discern ethical dimensions - everything goes when the job has to be done. The way how leaders' ethical/unethical behaviour affects their subordinates is being analysed in various research papers, the attention of investigators mostly is paid to aspects of leadership such as unethical behaviour of followers, multifocal social exchange perspective, trickle-down effect of ethical influence, phenomenon of social distance, relationship conflict and leadership of ethics. Given their positions in organisations, supervisors are often deemed legitimate models for normative behaviour (Mayer et al. 2012; Ghahroodri et al. 2013). The above-mention factors make it possible to develop the concept/model of the leadership of ethics (ELI, ethical leadership inventory) consisting of three phases (Spangenberg \& Theron 2005). The ELI interprets leadership as a complex, continuous process expressing itself in an extensive array of inter-dependent behavioural actions. The third level of ethical leadership presupposes existence of a common mission and vision. However, if leader's vision is inherently in conflict with the mission of the business or when the vision is centred upon the mission that is inherently unsupportable, the ethical leadership fails (Bowie 2005; Kaptein 1998; Sarwar 2013). As a rule, the transformational and charismatic leaders are thought to be ethical leaders who model ethical conduct (Brown \& Mitchell 2010), the same regards the authentic leaders (Walumbwa et al. 2008; Yukl 2008; George 2003). The contrast of the transformational as authentic leadership and transactional as inauthentic leadership is analysed by Groves and LaRocca (2011) and Turunc, Celik and Mert (2013), as well as by Brown, Trevino and Harrison (2005). The transformational leadership is defined as a process in which leaders and followers engage in a mutual process of raising one another to higher levels of morality and motivation (Turunc et al. 2013). It comprises five leadership dimensions: idealised attributes, idealised behaviours, inspirational motivation, intellectual stimulation and individualised consideration. Such leaders earn credit and respect from their followers by considering their needs above their personal needs and taking into account moral consequences of their key decisions (Groves \& LaRocca 2011). They influence others by developing collective vision and inspiring them to look for a common good, rather than their self-interest. A social learning perspective of ethical leadership proposes that leaders influence others via modelling (observational learning, imitation and identification). In our opinion, this construct of ethical leadership is the most fruitful as it allows (a) to develop a model of ethical leadership starting from the bottom up, that is, taking into account the particular business situation and ethical organisational culture, and (b) to work out specific criteria for management. Brown and others propose that leaders become attractive, credible and legitimate ethical role models by engaging in ongoing behaviours that are evaluated by

the followers as normatively appropriate (Brown et al. 2005). Table 1 summarises characteristics of the main models of ethical leadership. 
Table 1. Summary of ethical leadership comparisons (Source: Reed et al. 2011)

\begin{tabular}{|c|c|c|}
\hline Model & Similarities & Differences \\
\hline Transformational leadership & $\begin{array}{l}\text { Concern for others - altruism } \\
\text { Ethical decision-making } \\
\text { Integrity } \\
\text { Role modelling }\end{array}$ & $\begin{array}{l}\text { Ethical leaders emphasise ethical } \\
\text { standards and moral management } \\
\text { (more transactional) } \\
\text { Transformational leaders } \\
\text { emphasise vision, values and } \\
\text { intellectual stimulation }\end{array}$ \\
\hline Authentic leadership & $\begin{array}{l}\text { Concern for others - altruism } \\
\text { Ethical decision-making } \\
\text { Integrity } \\
\text { Role modelling }\end{array}$ & $\begin{array}{l}\text { Ethical leaders emphasise moral } \\
\text { management (more transactional) } \\
\text { and 'other' awareness } \\
\text { Authentic leaders emphasise } \\
\text { authenticity and self-awareness } \\
\text { (dark side - can have unrealistic } \\
\text { expectations of an unattainable } \\
\text { level of self-knowledge) }\end{array}$ \\
\hline Spiritual leadership & $\begin{array}{l}\text { Concern for others - altruism } \\
\text { Integrity } \\
\text { Role modelling }\end{array}$ & $\begin{array}{l}\text { Ethical leaders emphasise moral } \\
\text { management } \\
\text { Spiritual leaders emphasise } \\
\text { visioning, hope/faith, work as } \\
\text { vocation }\end{array}$ \\
\hline Servant leadership & $\begin{array}{l}\text { Concern for others - altruism } \\
\text { Integrity } \\
\text { Role modelling } \\
\text { Moral manager } \\
\text { Transactional/transformational }\end{array}$ & $\begin{array}{l}\text { Ethical leaders emphasise the } \\
\text { aspect of serving others, putting } \\
\text { their interests before the self- } \\
\text { interest }\end{array}$ \\
\hline
\end{tabular}

Apart from defining parameters of the ethical leadership, it is important, both theoretically and practically, to formulate the appropriate models of evaluation. A few questionnaires have been developed in recent years to measure the aspects of ethical leadership, but they differ in important ways and they all have limitations. The question of how to define and measure ethical leadership has not been resolved, and there is substantial conceptual confusion about this construct (Yukl et al. 2013). Brown and others have worked out 10-item instrument to measure perceptions of ethical leadership the Ethical Leadership Scale (ELS), which includes aspects such as (1) listening to what employees have to say; (2) disciplining employees who violate ethical standards; (3) conducting his/her personal life in an ethical manner; (4) having the best interests of employees in mind; (5) making fair and balanced decisions; (6) being trustworthy; (7) discussing business ethics or values with employees; (8) setting the behavioural example; (9) defining success not only by results but also by the way that they are obtained; and (10) always asking question 'what is the right thing to do?' (Brown, et al. 2005). In sum, the difference of this model from all others lies in the fact that evaluation is being performed by the employees. They define ethical leadership as the demonstration of normatively appropriate conduct through personal actions and interpersonal relationships and as the promotion of such conduct to followers through two-way communication, reinforcement and decision-making. Tanner and others criticise the ELS method for being rather abstract and not sufficiently specific regarding the ethical leadership. Moreover, they note that the ELS states that employees who evaluate leaders should be initially competent in the sphere of ethical behaviour. As a corrective, they developed a new measure the Ethical Leadership Behaviour Scale (ELBS). The ELBS focuses on visible ethical behaviour across different situations. The variables of this measure are the following: ethical leader behaviour, job satisfaction, affective commitment, work engagement, emotional exhaustion, health complaints, absenteeism, employee tenure and interaction frequency (Tanner et al. 2010). Kalshoven and others on the basis of the research mentioned above worked out the Ethical Leadership at Work Questionnaire (ELWQ) - the multidimensional measure of ethical leadership. They state that a leader's ethical behaviour consists of different behaviours that create different outcomes. The ELWQ consists of seven scales: people orientation, fairness, power sharing, concern for sustainability, ethical guidance, role clarification and integrity (Kalshoven et al. 2011). Amongst other measures of the ethical leadership 
measures/scales, we would like to mention also the TERA model - ethical questioning based on three aspects: knowledge, volition and action. The knowledge component aims, on one hand, to help individuals to identify their personal viewpoint and, on the other, to become aware of other ethical perspectives. The volitional component brings to light the axiological dimension, beliefs, standards and principle to which individuals subscribe in their daily professional activities. The action component, in its turn, presupposes the determination of considerations that would serve to defend the personal position (Langlois 2011). The normative model of ethical leadership evaluation consists of five subcomponents: society expectations, organisational values, norms and beliefs, outcomes, society evaluation and reconnection. This model is dynamic by its nature; it presupposes business ethics to be continuous and iterative process (Fryer 2011). Still, the most important for our current research is the ESLS elaborated by Reed, Vidaver-Cohen and Colwell (Reed et al. 2011). The scale in question consists of five first-order factors reflecting leadership attributes such as (1) interpersonal support, (2) building community, (3) altruism, (4) egalitarianism and (5) moral integrity. Whilst the Executive Servant Leadership is the second-order factor, it captures the idea that the above mentioned distinct but correlated factors, each measured by multiple items, can be explained by the higher-order construct, that is, by the ESL. Based on the factors and items put forward by Reed and others, a list of 55 statements was created. The current research on the ethical leadership perception amongst the Latvian retail trades makes use of adapted and shortened version of this questionnaire.

\section{Methodology}

The research project consists of three subsequent stages. First, we conducted two expert interviews with a representative from Latvian Retail Traders' Association and a researcher specialising in human resource management. As a result, we identified 20 items to measure the most significant aspects of servant leadership. The items were divided according to first-order factors (interpersonal support, building community, altruism, egalitarianism and moral integrity), coded (IS, BC, A, E, MI) and presented in a mixed order. Interpersonal support is offered by the top executives in the development of employees' potential and organisational culture. The main items operationalising the interpersonal support are, amongst others, helping other to succeed, nurturing employees' leadership potential, treating others with dignity and so on. Building community involves cooperation with the external community. Altruism means serving others willingly without expecting any reward, placing the interests of others before self-interest. Egalitarianism lies on the assumption that leaders are not inherently superior to others. Thus, the items of the egalitarianism are constructive criticism and input from employees, debating over ideas. Moral integrity, as represented in the ESLS, means behaviour that inspires employee trust and promotes transparency and honesty throughout the organisation. Both experts reviewed the list of statements, after that we did the necessary adjustments. Then we created the five-point Likert-type questionnaire (strongly agree to strongly disagree). The instrument was administered to a non-probability sample of 76 retail traders' in Riga that are outside the shop chains and buying groups (the total number of traders of this category in Riga is 76). The questionnaire was introduced as follows: 'We are conducting a survey on leadership ethics and leadership ethic evaluation among Latvian retail traders. We ask to respond to the statements regarding the top executive at the working place one accidentally chosen employee from each organization.' Data was collected, anonymity and confidentiality was guaranteed. Thirty participants filled out the questionnaire for a $39.47 \%$ response rate. In data analysis, we proceeded in three stages: first, we calculated the mean value for items within first-order factors; then we calculated the mean value for each first-order factor; and finally, we looked into some correlations between different groups of statements. The research questions are

1. What is the ranking of the Executive Servant Leadership first-order factors?

2. What are the possible problem areas in the ethical leadership as seen by the Latvian retail traders? 


\section{Results}

The respondents were asked to put a value on 20 statements. They were assured of the confidentiality. The results, that is, the mean values of each item (statement), are presented in Table 2.

Table 2. Mean values of the first-order factor items (Source: authors' compilation)

\begin{tabular}{|l|l|l|}
\hline Ranking & \multicolumn{1}{|c|}{ Statement } & \multicolumn{1}{|c|}{$\begin{array}{c}\text { Mean } \\
\text { value }\end{array}$} \\
\hline 1. & (BC) Encourages a spirit of cooperation amongst employees & 3.50 \\
\hline 2. & (IS) Listens carefully to others & 3.50 \\
\hline 3. & (IS) Treats employees with dignity and respect & 3.33 \\
\hline 4. & (E) Welcomes ideas and input from employees at all levels of the organisation & 3.30 \\
\hline 5. & (MI) Inspire employee trust & 3.17 \\
\hline 6. & (E) Encourages debate on his/her ideas & 3.13 \\
\hline 7. & (E) Invites constructive criticism & 3.07 \\
\hline 8. & (MI) Promotes transparency and honesty throughout the organisation & 3.07 \\
\hline 9. & (BC) Considers the effects of organisational decisions on the community & 3.00 \\
\hline 10. & (BC) Values diversity and individual differences in organisation & 2.97 \\
\hline 11. & (A) Places the interests of others before self-interest & 2.90 \\
\hline 12. & (IS) Look for ways to make other successful & 2.83 \\
\hline 13. & (MI) Models the behaviour he/she expects from others in the organisation & 2.83 \\
\hline 14. & $\begin{array}{l}\text { (BC) Believes our organisation has a duty to improve the community in which it } \\
\text { operates }\end{array}$ & 2.70 \\
\hline 15. & (MI) Freely admits his/her mistakes & 2.63 \\
\hline 16. & $\begin{array}{l}\text { (E) Displays interest in learning from employees, regardless of their level in the } \\
\text { organisation }\end{array}$ & 2.60 \\
\hline 17. & (A) Serves others willingly with no expectation of reward & 2.50 \\
\hline 18. & (IS) Nurtures employee leadership potential & 2.50 \\
\hline 19. & (A) Prefers serving others to being served by others & 2.37 \\
\hline 20. & (A) Sacrifices personal benefit to meet employee needs & 2.17 \\
\hline
\end{tabular}

IS, interpersonal support; BC, building community; A, altruism; E, egalitarianism; ME, moral integrity

Table 1 presents the ranking of assigned mean values to different statements related to different aspects (items) of the Executive Leadership Scale.

The next step was to calculate the mean value for each group of statements. The results are presented in Table 2.

Table 2. Mean values of the first-order factors (Source: authors' compilation)

\begin{tabular}{|l|l|}
\hline \multicolumn{1}{|c|}{ First-order factor } & $\begin{array}{l}\text { Mean } \\
\text { value }\end{array}$ \\
\hline Altruism & 2.48 \\
\hline Moral integrity & 2.93 \\
\hline Egalitarianism & 3.03 \\
\hline Interpersonal support & 3.04 \\
\hline Building community & 3.04 \\
\hline
\end{tabular}


Comparing the mean values, we can see that there are no significant differences between the factors, save the one of the altruism. Owing to the limited number of respondents, we cannot say that the results are conclusive; still we witness a tendency - the statements concerning the factor of altruism have received the lowest scores (the mean value of 2.48). Especially low ranked are statements such as 'Prefers serving others to being served by others' and 'Sacrifices personal benefit to meet employee needs'. This means that employees view their top managers as self rather than service orientated; thus an important aspect of ethical leadership is missing. In order to explicate this phenomenon, we juxtaposed the lowest ranked factor - altruism - with two equally high ranked factors, namely, building community and interpersonal support. If the coefficient between two answers is positive, for example, up to +1 , we can conclude that the answers are rather similar. If the coefficient is negative, it follows that the answers contradict each other. Our interest lies specifically with the negative coefficients, as they exhibit possible problem areas (see Table 3) worth for consideration.

Table 3. Comparative analysis of the first-order factor items (Source: author's compilation)

\begin{tabular}{|c|c|c|c|c|}
\hline & $\begin{array}{l}\text { Sacrifices personal } \\
\text { benefit to meet } \\
\text { employee needs (A) }\end{array}$ & \begin{tabular}{lr} 
Serves & \multicolumn{2}{r}{ others } \\
willingly with & no \\
expectations & of \\
reward (A) &
\end{tabular} & $\begin{array}{l}\text { Places the interests } \\
\text { of others before } \\
\text { self-interest (A) }\end{array}$ & $\begin{array}{l}\text { Prefers } r \text { serving } \\
\text { others to being } \\
\text { served by others (A) }\end{array}$ \\
\hline $\begin{array}{ll}\text { Considers } & \text { the } \\
\text { effects } & \text { of } \\
\text { organisational } \\
\text { decisions on the } \\
\text { community (BC) }\end{array}$ & 0.10 & 0.76 & 0.99 & 0.5 \\
\hline $\begin{array}{l}\text { Encourages a spirit } \\
\text { of cooperation } \\
\text { amongst employees } \\
\text { (BC) }\end{array}$ & -0.62 & 0.08 & 0.77 & -0.29 \\
\hline $\begin{array}{l}\text { Believes our } \\
\text { organisation has a } \\
\text { duty to improve the } \\
\text { community in } \\
\text { which it operates } \\
\text { (BC) }\end{array}$ & 0.83 & 0.97 & 0.73 & 0.98 \\
\hline $\begin{array}{l}\text { Vales diversity and } \\
\text { individual } \\
\text { differences in the } \\
\text { organisation }(\mathrm{BC})\end{array}$ & -0.17 & 0.57 & 0.9 & 0.25 \\
\hline $\begin{array}{l}\text { Look for ways to } \\
\text { make } \\
\text { successful (IS) }\end{array}$ & 0.35 & 0.88 & 0.98 & 0.69 \\
\hline $\begin{array}{l}\text { Nurtures employee } \\
\text { leadership potential } \\
\text { (IS) }\end{array}$ & 0.81 & 0.96 & 0.64 & 0.96 \\
\hline $\begin{array}{lr}\text { Treats } & \text { all } \\
\text { employees } & \text { with } \\
\text { dignity and respect } \\
\text { (IS) }\end{array}$ & -041 & 0.32 & 0.84 & -0.05 \\
\hline $\begin{array}{l}\text { Listens carefully to } \\
\text { others (IS) }\end{array}$ & -0.57 & 0.14 & 0.31 & -0.24 \\
\hline
\end{tabular}

IS, interpersonal support; BC, building community; A, altruism; E, egalitarianism; ME, moral integrity

At first, let us look into correlations between altruism and building community, paying attention to negative coefficients. Amongst all coefficients, three of them are the negative ones (ranking between -0.17 and -0.62 . The latter one pertains the relation between two items 'Sacrifices personal benefit to 
meet employee needs' $(A)$ and 'Encourages a spirit of cooperation amongst employees' $(B C)$. As the answers are opposite (coefficient -0.62), we can detect the most significant problem related to the ethical leadership in the surveyed organisations, that is, the exclusion of the leader from the truly collaborative effort. In other words, although the leader encourages team spirit, he/she is not a part of that team, acting as a direction-giving outsider. Second, juxtapositions of the items of altruism and interpersonal support exhibit four negative coefficients, respectively, $-0.05,-0.24,-0.41$ and -0.57 . Let us consider the last two coefficients. Coefficient -0.41 is a cross-point between the item of 'Treats all employees with dignity and respect' $(I S)$ and 'Sacrifices personal benefit to meet employee needs' $(A)$. The possible leadership ethics problem lies in the fact that the leader, though ready to treat employees respectfully, is not ready to give up his/her personal interest even for a good cause, when it does not suit him/her. The coefficient -0.57 delineates another problem - leaders, according to employees, are not interested to take into account their opinion. This undermines the very principle of the Executive Servant Leadership, in which altruism is one of the key factors. Although our research does not yield the conclusive results because of the limited number of participants, we believe that the factor analysis demonstrates tendencies and allows determining the critical areas of ethical leadership in the surveyed organisations, namely, the employee believes that their leaders do not exhibit qualities associated with altruism, placing their self-interest first. There can be a number of reasons for this, for example, the disregard for long-term goals of organisation (sustainability) on the part of leaders, the miscommunication and the cognitive dissonance between expectations of both parties (employees and leaders). These aspects should be researched further - by quantitative survey amongst employees and by follow-up interviews paying a special attention to the items of altruism factor.

\section{Conclusions}

The current article is devoted to the study of the concept of ethical leadership and its various interpretations in the theoretical literature as well as to the description of various evaluation scales in order to determine the most suitable for the Latvian retail trade organisations. After reviewing a number of evaluation models, we propose that the most applicable one is the ESLS, as it takes into account various aspects of leadership and gives voice to employees. There are several conceptions of ethical leadership - the transformational leadership is aimed at vision, values and intellectual stimulation; the authentic leadership emphasises the moral management; the spiritual leadership sees the work as passion and vocation; the servant leadership is characterised by putting interests of others before the self-interest. Amongst various measures of ethical leadership, we can mention the ELS, the ELBS, the ELWQ, the TERA model and the ESLS. The ESLS differs from other models because it is related to practical business management strategy and ethical accountability through the principle of sustainability. The conceptual model of the ESLS consists of five first-order factors: Interpersonal Support, Building community. In the empirical part of the research, we put forward two research questions: (1) What is the ranking of the ESLS first-order factors? and (2) What are the possible problem areas in the ethical leadership as seen by the Latvian retail traders? The answers to them in details are given in the article, but, in sum, we can state that the ranking of the first-order factors is the following (from the highest to lowest position): Building Community and Interpersonal Support, Egalitarianism; Moral Integrity, Altruism. The lowest mean value was signed to the factor of Altruism; this means that employees believe that their leaders do not exhibit qualities associated with altruism, placing their self-interest first and this does not facilitate the social accountability and sustainability of business organisation. The comparative first-order factor item analysis illuminated specific aspects need to be research in future, mostly related to the items of Altruism.

\section{References}

Bowie N. E. (2005). Expanding the horizons of leadership. The Quest for Moral Leaders. Essays on Leadership Ethics. Cheltenham, UK \& Northampton, MA, USA: Edward Elgar, 144-160.

Brown, M. E., Trevino, L. K., \& Harrison, D. A. (2005). Ethical Leadership: A Social learning perspective for construct development and testing. Organizational Behavior and Human Decision Processes, 97, 117-134. 
Brown, M.E., \& Mitchell, M.S. (2010). Ethical and Unethical Leadership: Exploring New Avenues for Future Research. Business Ethic Quarterly, 20, 583-616.

Fryer, M. (2011). Ethics and Organizational Leadership: Developing a Normative Model. Oxford: Oxford University Press.

George, B. (2003). Authentic Leadership. Rediscovering the Secrets to Creating Lasting Value, San Francisco, CA: Jossey-Bass.

Ghahroodri, H. K., Ghazal, M. Z., \& Ghorban, Z. S. (2013). Examining ethical leadership and its impact on the followers' behavioral outcomes. Asian Social Science, 9, 91-96.

Groves, K. S., \& LaRocca, M. A. (2011). An Empirical Study of Leader Ethical Values, Transformational and Transactional Leadership, an Follower Attitudes Towards Corporate Social Responsibility, Journal of Business Ethics, 103, 511-528.

Kalshoven, K., Den Hartog, D. N., \& De Hoogh, A. H. B. (2011). Ethical leadership at work questionnaire (ELW): Development and validation of a multidimensional measure, The Leadership Quarterly, 22, 51-69.

Kaptein, M. (1998). Ethics Management. Auditing and Developing the Ethical Content of Organizations, Dortdrecht: Kluwer Academic Publishers.

Langlois, L. (2011). The Anatomy of Ethical Leadership. Edmonton: AU Press.

Marsh, C. (2013). Business Executives' Perceptions of Ethical Leadership and Its Development. Journal of Business Ethics, 114, 565-582.

Mayer, D. M., Aquino, K., Greenbaum, R. L., \& Kuenzi, M. (2012). Who displays ethical leadership, and why does it matter? An examination of antecedents and consequences of ethical leadership. Academy of Management Journal, 55, 151-171.

Palmer, D. E. (2009). Business Leadership: Three levels of ethical analysis. Journal of Business Ethics, (88), 525-536.

Reed, L. L., Vidaver-Cohen, D., \& Colwell, S. R. (2011). A New Scale to measure Executive Servant Leadership: Development, Analysis, and Implications for research. Journal of Business Ethics, (101), 415-434.

Sarwar, C. I. (2013). Future of Ethically Effective Leadership, Journal of Business Ethics, 113, 81-89.

Spangenberg, H., \& Theron, C. C. (2005). Promoting ethical follower behavior through leadership of ethics: The development of the ethical leadership inventory (ELI). South African Journal of Business management, 36, 1-18.

Tanner, C., Brügger, A., van Schie, S. \& Lebherz, C. (2010). Actions Speak Louder Than Words. The Benefits of Ethical Behaviors of Leaders, Journal of Psychology, 218, 225-233.

Turunc, O., Celik, M., \& Mert, I. S. (2013). The Impact of Leadership Styles on Ethical Behavior. Journal of Academic Research in Economics, 5, 60-85.

Walumbwa, F. O., Avolio, B. J., Gardner, W. L., Wernsing, T. S., Peterson, S. J. (2008). Authentic Leadership: Development and validation of a theory-based measure, Journal of Management, 35, 89-126.

Yukl, G. (2008). Leadership in Organizations. Upper Saddle River, Boston, Columbus, San Francisco, New York, Indianapolis, London, Toronto, Sydney, Singapore, Tokyo, Montreal, Dubai, Madrid, Hong Kong, Mexico City, Munich, Paris, Amsterdam, Cape Town: Pearson Education.

Yukl, G., Mahsud, R., Hassan, S., Prussia, G. E. (2013). An Improved Measure of Ethical Leadership. Journal of Leadership \& Organizational Studies, 20(1), 38-48.

Zaccaro, S .J., Gulick, L. M., \& Khare, V.P. (2008). Personality and Leadership. Leadership at the Crossroads, Wectport, CT: Praeger Publishers, 13-29. 